Published in a revised version as Davies, S., HAMMER, N., Williams, G., Raman, R., Ruppert, C.S., and Volynets, L. (2011) Labour Capacity in Global

Subcontracting Chains. Evidence from a Construction MNC, Industrial Relations Journal 42 (2). ISSN 1468-2338

\title{
Labour capacity in global subcontracting chains: evidence from a construction MNC
}

Steve Davies, Nikolaus Hammer, Glynne Williams, Rajeswari Raman, Clair Siobhan Ruppert and Lyudmyla Volynets ${ }^{1}$

\section{Abstract}

The Building and Wood Workers' International has concluded agreements with MNCs which contain particularly strong provisions to enforce fundamental labour rights in the subcontracting chain. This paper evaluates their use and effectiveness at national and local level via an international comparison of practices in Hochtief, a German MNC.

Word Count: 8,518

\footnotetext{
${ }^{1}$ Steve Davies is Senior Research Fellow at the Cardiff School of Social Sciences, UK. Nikolaus Hammer and Glynne Williams are Lecturers in Employment Studies at the Centre for Labour Market Studies, University of Leicester, UK. Rajeswari Raman is a researcher at the Malaysian Trades Union Congress (MTUC), Malaysia. Clair Siobhan Ruppert works for the Central Única dos Trabalhadores (CUT), Brazil. Lyudmyla Volynets is a doctorate researcher at the Otto Suhr Institute for Political Science, Freie Universität Berlin, Germany. Correspondence should be addressed to Nikolaus Hammer, CLMS, University of Leicester, 7-9 Salisbury Road, Leicester LE1 7QR, UK; email: nikolaus.hammer@le.ac.uk
} 
Key Words: labour capacity, subcontracting, labour rights, union organisation, construction 


\section{Labour capacity in global subcontracting chains: evidence from a construction MNC}

Faced by the deregulation of the industry in recent decades, and significant increases in informal employment and migrant labour, construction unions had to find new forms of international cooperation and exercising industrial power. In this context, the Building and Wood Workers' International (BWI) focused on the terrain of multinational corporations (MNCs) to build coordination networks, organise workers in MNC subsidiaries and subcontractors, and establish social standards that address key problems within the sector. International Framework Agreements (IFAs) with MNCs have become an important plank in BWI's strategy, agreements that embrace the core labour standards embodied in the ILO's 1998 Declaration of Fundamental Rights at Work as well as a range of industry-specific Conventions. Importantly, agreements in this sector often contain very strong provisions with regard to compliance with core labour standards and specifically commit construction MNCs to enforcing compliance in the subcontracting chain (see Hammer, 2008; 2005). BWI aims to use them to link union strategies across borders, organise around the protection of fundamental social and labour rights, and thereby grapple with the highly fragmented inter-firm relations and employment contracts that prevail in the industry.

Construction has not escaped the fashion of deregulation and the pressures of economic globalisation (e.g. Bosch and Philips 2003; ILO 2001; EMCC 2005). In fact, its contrasting features - the local, project-based and relatively labour-intensive 
character of construction, together with the relative mobility of labour, materials and services - were restructured in a neo-liberal framework (e.g. Lillie and Greer, 2007). On the one hand, tiered subcontracting chains link the project management and financing of civil engineering MNCs with layers of smaller and more place-bound companies (e.g. in residential building). On the other hand, significant increases in labour migration and informal employment co-exist with the local fixity of construction. Over the last three to four decades the industry has become a major employer of migrant labour, overwhelmingly in informal employment which was put at between 75-95\% in countries such as Brazil, India, and Malaysia (Wells, 2007; ILO, 2001). In industrialised countries trends of casualisation have come as selfemployment, often described as false self-employment in cases where workers are $d e$ facto employees without many of the statutory protections arising out of direct employment (Davies, 2008; Harvey and Behling, 2007). In the European Union (EU) cross-border subcontracting and 'posting' of workers has led to significant labour migration in the sector as well as pressure on existing social and labour standards (Cremers et al, 2007).

These developments raise important questions about the ways labour can build local capacity as well as international coordination across subcontracting chains which effectively exploit varying national regulatory frameworks of the employment relationship and trade union governance, as well as major differences in local labour regimes (Castree et al, 2004). How can social standards be implemented and protected in such a context? Going beyond the question of securing labour rights in subcontracting chains, another crucial issue arises with regard to the sustainability of any advances made. The project-based nature of construction in particular carries the 
threat that work on core labour standards, trade union organising, or corporate social responsibility (CSR) takes on a Sisyphus-type character once the contract is finished and the parties involved move on. More specifically with regard to IFAs, these developments raise questions as to how their central tenet - compliance with fundamental labour rights - squares with the fundamental issue of power in international industrial relations arrangements: the guarantee of the freedom of organisation does not automatically result in an organised workforce and sound bargaining structures. It needs to be asked to what extent local trade union organisation can be an outcome of an IFA or to what extent the former needs to be seen as a prerequisite of the latter. However, apart from early case studies on Accor (Wills, 2002) and Chiquita (Riisgaard, 2005) where subcontracting did not play any part, the role of IFAs at the local level has only been researched to a very limited extent.

The tiered and fragmented character of the construction industry as well as the global-local nature of building labour capacity via labour rights campaigns pose a number of substantive and methodological challenges in researching IFAs. In this paper, we explore labour's use of an IFA that was concluded in 2000 between BWI and the German construction MNC Hochtief. We employ a matched comparison of the divisions, subsidiaries and subcontractors in Hochtief's German, Brazilian, Malaysian and Ukrainian locations. The case studies are based on an analysis of the IFA and CSR policies, interviews with management and global union officers in charge of the implementation and coordination of monitoring, as well as interviews with national and local trade union officers (15 interviews in total). They involved an international network of researchers who are active trade unionists and recent 
graduates of the Global Labour University ${ }^{1}$, thereby ensuring respect for societal differences in the industry, local practices of work and employment, political discourse and strategies. Thus, the focus was on local labour practices rather than a 'catalogue of diversity' (Hyman, 2001: 205) dealing with IFAs as a function of MNC or GUF strategies ${ }^{2}$. We focus on the actual use of a particular agreement, mediated by national institutions and trade union strategies, and analyse the potential of IFAs to open a space for trade union organisation, a space or an organisation which is sustainable. Furthermore, we look at how transnational trade union cooperation has linked the local, national and global levels in pursuing the goals of the IFA.

The next section introduces the particular challenges for the social regulation of employment resulting from complex subcontracting networks as well as segmented labour markets (the use of informal labour). After an analysis of the BWI's strategy on working with IFAs we introduce case studies of the functioning and use of the Hochtief IFA in Brazil, Malaysia and Ukraine. A key concern is a) whether and how the agreement has opened spaces for trade union organising and international cooperation, and b) with the way trade unions in subcontracting chains are drawn into the remit of the lead MNC's industrial relations.

\footnotetext{
${ }^{1}$ See www.global-labour-university.org

${ }^{2}$ A recent example of similar intention is the action research design utilised by Hale and Wills in the textile sector (2005).
} 


\section{Construction subcontracting: outsourcing local}

\section{labour control}

The construction industry is highly segmented in a functional as well as a spatial sense, which - in addition to the project-based character - seems to put a premium on technology, organisational, and relational rents (see e.g. Bosch and Philips, 2003; ILO, 2001; EMCC, 2005). While large segments in the industry, often the labourintensive aspects of building construction, installation and completion, do have relatively low entry barriers, those thresholds are higher in materials supply, civil engineering services as well as general contract management. Particularly the latter have seen a geographical expansion together with consolidation and industrial upgrading. Compared with other value chains, however, the construction industry is dominated by an extremely tiered structure which is driven by the general contractors and/or developers/clients at the downstream end of the chain.

Although value chains in the construction industry vary markedly according to the national context, it is possible to highlight a number of features and trends that characterise the industry from a global perspective. First, we can observe a polarisation within the global value chain: whereas the materials suppliers and civil engineering services have seen the consolidation and emergence of large MNCs (e.g. Lafarge, Hochtief), the building sector (installation and completion) is invariably dominated by small and medium-sized enterprises (EMCC, 2005: 6). Second, what this picture captures, in a historical perspective, is the rise and expansion of large enterprises at international level at the same time as they move up the value chain into areas of civil engineering services, contract management as well as various 
public-private forms of operation. Third, whether part of a global value chain or within a national segment, the industry is characterised by extensive subcontracting networks. Outsourcing over the last three decades meant that value chains were restructured considerably. As large companies tried to concentrate on management and coordination functions of construction projects or of servicing those projects and the finished buildings, there was an increase in the number of smaller companies that take on delimited and specialised parts of construction.

The above developments had very significant implications for employment and labour. While the sector has grown considerably over the last decades, competitive pressures and regulatory opportunities led a large number of companies to outsource lower-end functions and shed labour. This lies at the core of the massive growth of the informal economy, particularly in developing countries but also in the industrialised world (Wells 2007; ILO 2001; ILO 2002).

If all of the construction workers who are employed on a casual basis, without regular contracts or any social protection, are included in the expanded concept of the 'informal economy', then it is clear that informality is now the norm, rather than the exception, in the construction industry throughout much of the developing world. (Wells 2007: 91)

In this process, local construction labour markets, which are essentially embedded in local conditions of work and employment, have been drawn into the dynamics of international restructuring. Emerging local labour control regimes (Castree et al, 2004; Burawoy, 1985; Williams, 2008) mediate the outsourced, local performance of construction work - carried out by informal and migrant (internal or international) labour, managed via labour intermediaries - and the extensive subcontracting chains 
that exert constant pressures on wage levels (often below living and minimum wages), employment conditions (e.g. working time, high rates of occupational injuries) and living conditions (reflecting exploitative and/or paternalistic settings).

In Malaysia, for example, employment in the construction sector almost tripled from 270,000 workers to 746,000 in 1997 ; in $199280 \%$ of the entire construction workforce was estimated to be made up of Indonesian migrant workers. Workers are recruited and supervised by intermediaries, so-called kepalas, who have established themselves as labour subcontractors. In 1998 the proportion of foreign workers that was employed by subcontractors was put at 75\% (ILO, 2001; Narayanan and YewWah, 2005). By contrast, the sixfold rise in the Brazilian construction workforce was fuelled by internal labour migration. While states like São Paulo and Rio de Janeiro recorded more than $90 \%$ of migrant construction workers in 1985 , the overall proportion of migrants in construction has declined to $43 \%$ in 1996. In the same period though, the number and role of intermediaries (gatos) rose considerably and between 1981 and 1999 the number of unregistered and self-employed workers rose from $56.7 \%$ to $74.6 \%$ (ILO, 2001).

The ILO (2001: 24) recognises that outsourcing offers flexibility in the use of labour as demand for particular construction products varies and skills for different products are not homogenous. Another way of putting this advantage, however, is to emphasise the delegation of labour control and social wage issues, i.e. the 'outsourcing' and 'delegation' of factory regimes. Subcontracting informal labour means that international construction materials and services providers can dissociate themselves from the forms of control as well as the working and living conditions of 
the bulk of the local workforce. The question we try to address in the following sections is how unions can employ IFAs to counter the subversion of fundamental human, social and labour rights.

\section{BWI and International Framework Agreements in construction}

Like other Global Union Federations (GUFs) the BWI (and its predecessor, the IFBWW) has developed a strategy in the last two decades to engage with and counter the rising power of MNCs. The approach is accompanied by information, education and training in order to encourage affiliates 'to use framework agreements as a tool for organising' (IFBWW, 2003: 3). With the signing of an IFA with IKEA in 1998 the BWI was among the first GUFs to embark on this strategy and has since signed 15 IFAs in total, 9 of which were concluded with construction MNCs (see Table 1). What is particular to the development of BWI's IFAs is, first, that recent agreements tend to commit to a wider range of ILO Conventions that are particularly relevant to the sector, e.g. including wages (C94, C95, C131), the reduction of working hours (C1, C47, Rec116) and occupational health and safety standards relevant to construction (C155, C161, C162, C167). Generally, there is explicit mention of the importance of establishing an employment contract, and some agreements contain strong language on living wages (see those concluded by Impregilo, Italcementi, Royal BAM, Veidekke, VolkerWessels). Further, a number of IFAs also refer to ILO 
standards and tools in the area of health and safety ${ }^{3}$. Second, the agreements establish explicit responsibilities and routes of reporting, mostly via a reference/monitoring group which reports to the MNC's Executive Board. Third, these IFAs often contain strong provisions regarding the MNC's subcontractors and suppliers; in fact, Hochtief, Skanska, Impregilo, and VolkerWessels regard compliance as mandatory.

Insert Table 1 about here.

The BWI has recognised that concluding agreements only constitutes the first step in a process towards labour rights, particularly given the challenges posed by the project-based character of construction, complex and changing subcontracting chains, as well as vastly differing labour market structures, employment regulations, and trade union capacity. However, some BWI affiliates have developed distinct ways of working with IFAs. For example, a number of national and international trade union activities have been geared towards providing information about IFAs, training on organising, and building networks in MNCs. Equally, some affiliates organised their international projects to follow and monitor their home country MNCs and to support trade union campaigns, organisation and capacity building in foreign locations. The Dutch construction unions in particular have repeatedly monitored Netherlands-based construction MNCs in the Gulf region (BWI, n.d.a; BWI, 2007a); Dutch and Swiss construction unions have used building projects for

\footnotetext{
${ }^{3}$ See, for example, the ILO Code of Practice on HIV/AIDS and the World of Work (Impregilo, Italcementi, Lafarge, Royal BAM, Veidekke, VolkerWessels), the ILO Guidelines on Occupational Safety and Health Management Systems (Italcementi, Lafarge, Royal BAM, Veidekke, VolkerWessels), the ILO Code of Practice on Safety and Health in Forest Work (Italcementi, Veidekke), and the ILO Code of Practice on Safety in the Use of Synthetic Vitreous Fibre Insulation Wools (Italcementi, Veidekke).
} 
the 2010 football world cup in South Africa to monitor contractors and start a dialogue with the international football association FIFA (BWI, 2008). A number of these initiatives and missions form part of the regular review processes of the respective IFAs. Visits by the reference/monitoring groups can provide a platform for fact finding in MNCs' foreign operations, to address problems, as well as to create capacity for trade unions and social dialogue. A visit to review the Tanzanian Veidekke subsidiary Noremco, for example, resulted in an agreement that 'local management, Tamico [Tanzanian construction union] and field branch committee will meet every 6 months to review the implementation' with basic information on health and safety, wages, education and training, working hours, and type of employment contracts to be provided by management (BWI, 2007c). Subsequently, a collective bargaining agreement was signed between Tamico and Noremco.

Another important function of framework agreements is that conflicts can be raised with central management at the headquarters. An IFBWW (2004) review, for example, mentions a complaint about organising a construction site of Hochtief's US subsidiary Turner, a conflict that was resolved after the intervention of Hochtief's home-country union IG BAU. In Skanska it was the monitoring group that dealt with complaints from Peru ('concerning the local management, salary scale, canteen and food, milk provisions, reemployment of staff'), Germany (on employment/dismissal of Polish workers), and the US (on unfair labour practices). While the review reports good management-union relations in Ballast Nedam's Ghanaian operations, it also states that 'due to the critical economic situation of the company and time constraints, there has been no monitoring group meeting or any follow-up of the agreement.' (IFBWW, 2004: 14) Another protracted conflict in one of Lafarge's 
Korean subcontractors, however, shows the difficulties of enforcing the provisions not only of the IFA but also the decisions of the Labour Relations Commission in subcontractors (see BWI, 2007b). In March 2006, Woojin Industry, one of Lafarge Halla Cement's in-house subcontractors, closed down after 21 of its 35 workers joined the Korean Chemical and Textile Workers Federation (KCTF). While workers who retracted their union membership were employed in other subcontractors of Lafarge, this was refused to unionised workers, even though the Regional Labour Relations Commission ruled twice that Lafarge, which is taken to have managerial control over Woojin Industry, has unfairly dismissed the workers. The KCTF members launched a campaign including a sit-down strike in front of their plant, sought mediation from the Ministry of Labour, and engaged the Regional Labour Relations Commission and the National Contact Point dealing with the OECD Guidelines for Multinational Enterprises. They also went to France to meet management at the Lafarge headquarters as well as home-country unions. In early 2007, two KCTF officers started a hunger strike in front of Lafarge's Seoul office. In March 2007, the National Labour Relations Commission overturned the ruling of the Regional Commission; in reaction, the KCTF appealed to the Ordinary Court (TUAC, 2007: 39). With the BWI's help, an agreement has since been made that included re-employment for the concerned workers (Interview, BWI official).

Thus, although the IFA commits the MNC and its subcontractors to the same standards, in terms of individual and collective labour rights, there is rarely any formal mechanism to translate this into consistent practice. Clearly, the global reach of these companies is itself an obstacle: "the further you go away from your [home base] the more difficult things become" (Interview, Hochtief manager). It is equally 
apparent that the complex structure of subcontracting provides the basis for outsourcing responsibility, or, in the worst cases, for 'plausible deniability'. The most immediate problem facing unions is one of monitoring and verification. The role of the joint reference group, where such a body exists, is inevitably limited, although in some cases, country visits have been made by union-management teams. The detailed monitoring of compliance, however, is often outsourced to commercial auditing companies, and this arrangement, according to BWI, has clear shortcomings such as

...the auditors' ignorance about labour rights issues or the realities of working conditions; the extraordinary scale of subcontracting chains in our industries, which would require an army of auditors to verify compliance with the standard; and the marginalization of trade unions in the representation of workers' interests. (Hellmann, 2006: 4)

The reporting of IFA infringements has been largely reliant on a local trade union presence, yet, according to BWI, "only a handful" of unions have actively used these agreements (Hellmann, 2006: 4). Given that the most serious infringements might reasonably be expected to occur in unorganised workplaces, this raises an obvious and fundamental problem. Particularly with respect to freedom of association provisions, the question is whether internationally negotiated commitments can potentially provide the platform for union organising, rather than just act as an additional tool for already well-organised unions. 


\section{Using the IFA in Hochtief: global negotiation, local organising?}

In the following we examine how responsibility for fundamental labour rights is implemented, monitored and 'outsourced' in different ownership and subcontracting arrangements as well as local labour regimes. This is discussed in the context of evidence from union activists from Hochtief divisions, subsidiaries and subcontractors in Brazil, Malaysia and Ukraine.

\section{The virtual construction company}

Hochtief describes itself as 'an international construction services provider' (Hochtief, 2007a: 2). Headquartered in Germany, it claims to be the world's third largest and most international company in the construction industry. In 2006 its sales were Euro 15,508 million, $86.3 \%$ of which were realised outside Germany; total employee figures stood at 46,847 of which almost $80 \%$ worked outside the home country, up from $74.5 \%$ in 2002 . Over the last decades Hochtief has developed its global reach as well as coverage of the entire construction value chain. In particular, it has consolidated its position in the higher end parts of the chain, for example in construction related services via public-private partnerships where it finances, builds and operates infrastructure projects, as well as in facilities management. Hochtief's worldwide construction services activities are organised on a regional basis, supported by corporate divisions in particular business areas (airport, development) and functional divisions such as project management and insurance. 
The Americas division consists of the Turner Corporation in the US and Hochtief do Brasil. Turner is the leading general builder in the US, the world's largest construction market. The Asia Pacific division has a strong position in Australia through its majority holding in the Leighton Group, which spans the entire construction value chain. Leighton has also secured important positions in growth markets elsewhere with Leighton Asia as well as the Al Habtoor Leighton Group in the Gulf region. Leighton holds $45 \%$ in the latter which is mainly active in Dubai, Abu Dhabi and Qatar with a perspective to expand into new markets in the Middle East and North Africa. Al Habtoor Leighton has more than 2,000 projects under development in the Gulf region and employs around 30,000 people (Leighton, 2007). Hochtief Construction Services Europe is active in Germany, the UK, Austria, Poland, the Czech Republic, and Russia and Ukraine.

Hochtief sees itself as pioneer in social responsibility and sustainability, claiming that it is the only company in the sector in Austria, Germany, and Switzerland, to publish a comprehensive report on those issues (Hochtief, 2007b). Its sustainability report follows the guidelines of the Global Reporting Initiative and was audited by PricewaterhouseCoopers. The company is also listed on the Dow Jones Sustainability Indices. Underlining the role of CSR in the Group, a CSR committee was established in 2007 which includes a range of representatives from corporate functions as well as the works council. Formally, the committee meets quarterly, is responsible for implementing 'CSR thinking' in all Hochtief divisions, and reports and formulates recommendations to the Executive Board (Hochtief, 2007b). In the words of a senior union official in the company: "the highest employee 
representative and the highest employer representative meet, that could be at a weekly level, that is how it is lived" (Interview). So far, there is no specific review or application group of the IFA, although the BWI, IG BAU and General Works Council members regularly meet union representatives in Hochtief subsidiaries.

Formally, then, the monitoring mechanism is universal. However, whereas there have been no issues under the IFA in Europe - "We didn't expect any major problems and we don't have them" (Interview, Hochtief manager) - important differences arise internationally in the company's approach to labour rights. The Leighton Group, for example, publishes its own CSR report, and Hochtief admits to limited influence in applying IFA terms, formally as well as in practice:

Due to the regional characteristics specific company guidelines and ethics guidelines apply to Leighton. (Hochtief, 2007b: 4)

Leighton is a publicly traded company. We own more than $50 \%$ so we have a certain influence. But it is an independent company; other than talk to people and try to convince them... (Interview, Hochtief manager)

Hochtief has a well-developed dual approach of corporate social responsibility on the one hand, and industrial relations on the other. Whereas certainly BWI, IG BAU and the General Works Council have good access and a constructive working relationship with company headquarters, formal industrial relations mechanisms remain concentrated in those divisions and countries where collective bargaining is part of traditional management-labour relations. 
To some extent, this reflects ownership structures which tend to be more arm'slength the more the institutional and regulatory framework differs from the home country. At the same time, though, this fragmented approach to social and labour rights does not mean that Hochtief has no managerial authority at all along the subcontracting chain. Hochtief operates a "cross-divisional competence center for occupational safety and health and environmental protection (OSHEP center)" which is responsible for implementing and monitoring the OSHEP Directive, applicable throughout the Group. This centre is led by the president of the General Works Council and has around 30 staff and has so far overseen the external certification of more than $50 \%$ of Hochtief's corporate units ${ }^{4}$ (Interview, Hochtief union official; Hochtief, 2007b: 13). In this area, the company has developed strong compliance provisions for suppliers:

[W] will also require contractors and suppliers to comply with a Code of Conduct which we have formulated. In this, we will, for instance, require compliance with international standards on ethical conduct, respect for the basic rights of employees and guaranteed measures regarding safety and environmental protection. There will be a provision that we have the right to check, at any time and unannounced, whether subcontractors and suppliers are complying with this planned Code of Conduct. In the event of any breaches of this, Hochtief reserves the right to terminate the business relationship.

(Hochtief, 2007b: 21)

With regard to the fundamental labour rights contained in the IFA, however, the sustainability report merely states:

\footnotetext{
${ }^{4}$ Certification according to SCC (Specialist Contractors Confederation), OHSAS 18001, AS 4801 (Australia) (Hochtief, 2007b: 35)
} 
This represents an undertaking to adhere to the standards with regard to the rights of our own employees and the employees of our partners. (Hochtief, 2007b: 21)

Thus, the international construction services provider is a 'virtual' construction company insofar as it focuses on high-end activities with only limited involvement in actual building. Any effort to regulate the terms of work and employment therefore has to go beyond its organisational remit and, in effect, is a test of the industrial and managerial power of the lead company vis-à-vis its subcontractors. At the same time, though, the terrain of this test might open up opportunities for union organisation.

\section{Monitoring and Implementation}

The International Framework Agreement between Hochtief and BWI (then IFBWW) was concluded in 2000 as the first IFA in the construction industry and takes up a number of the pressing issues facing work and employment in the industry. The General Works Council and IG BAU (the German Construction Workers' union) were co-signatories. Hochtief commits to respect the ILO core labour standards as well as other, more general, standards: 'adequate' wages, 'reasonable' working time, and 'decent' working conditions. There is no permanent reference group and the formal role of the unions in monitoring and review is only sketchily defined. In the event of infringements, for example, the unions "will report this contravention to the Executive Board of HOCHTIEF. This body will examine and introduce suitable measures to remedy the issue" (Hochtief et al, 2000). As will be seen, however, in 
the absence of a properly resourced audit procedure, implementation is largely dependent upon union organisation and vigilance.

Similar to most other IFAs in the construction industry, compliance with these provisions is, ostensibly, mandatory for suppliers:

HOCHTIEF requires that its contractual partners shall support this Code of Conduct and shall also ensure that it is adhered to by any of their contractual partners who are in any way active in connection with the business activity of HOCHTIEF. (Hochtief et al, 2000)

However, this seemingly all-encompassing definition of 'partners' is subject to interpretation. Not only is there no systematic enforcement of the agreement in subcontractors; in effect, the terms of the agreement are applied differentially, or not applied at all, by Hochtief's own regional subsidiaries. For example, Leighton, in which Hochtief is the largest shareholder, is excluded from the remit of its social responsibility strategy. In the case of Malaysia, Leighton does not recognise the Union of Employees in the Construction Industry (UECI) for collective bargaining. This means that the union is limited to individual representation, either through the company's internal procedures or at Industrial Court, and UECI attempts to recruit on that basis. Organisers report that "at first sight", workers "were not keen to see Union people as they were too scared" (UECI, 2007). More particularly, the scope for organisation is limited by the structure of contracting and by national labour law.

In Ukraine, issues of governance are, in some ways more straightforward. Projects are managed through Hochtief's own European division and work on site is carried 
out by a relatively small number of major contractors. Sub-contracting tends to be limited to 'non-core' activities and the multi-tiered subcontracting seen in Western Europe is a relatively recent import, associated with foreign ownership in the sector. For example, the largest Ukrainian project, the sports stadium at Dnipropetrovsk, involved fewer than 30 companies; (typically, comparable projects may involve 1,000 contractual links; Stansbury, 2005: 38). This structure might be expected to facilitate communication of the company's commitments down the contracting chain. However, of four major contractors surveyed at the Dnipropetrovsk project, only one was able to report any knowledge of the IFA (Interviews). The terms of the IFA were not included in contract documentation; in the one case where management had heard of the IFA, this had arisen in discussion with Hochtief in Ukraine.

Hochtief is well-established in the Brazilian market through its subsidiary, Hochtief do Brazil. The construction workers' union, CONTICOM, has affiliates which attempt to organise Hochtief sites in three Brazilian cities. In this case the task of disseminating the IFA is complicated by the growth of sub-contracting, much of it to small local firms (Villagarcia and Cardoso, 1999). An equally important constraint on CONTICOM is Brazilian collective labour law, which prescribes city-specific unions. Of 500 construction unions, 90 are affiliated to CONTICOM-CUT. In the case study Hochtief site in the state of São Paulo, the president of the local union was not aware of the IFA. The union does not represent any subcontracted workers, only Hochtief employees. Although the company claims that "the right of Hochtief employees to be members of a trade union is expressly welcomed" (2007b: 31), restrictions on organisation make it almost impossible to extend this welcome to 
contractors. For example, all meetings with members or potential members have to be conducted off-site.

Effectively, then, Hochtief operates a four tier approach to the IFA. The first tier comprises Hochtief's direct workforce, where industrial relations reflect the strength of the IG-BAU. Second are the regional subsidiaries and joint ventures, which are allowed considerable latitude to capitalise on restrictive labour legislation. Third are the subcontractors. The evidence suggests that IFA terms are not routinely communicated, and the Ukrainian case demonstrates that, even where relatively few contractors are involved, there is almost no awareness among managers of their obligations.

The fourth tier is the informal labour that makes up the bulk of the workforce in all three countries. The term 'informal' labour is used in a variety of ways to describe a range of worker statuses of varying vulnerability (Wells, 2007). The crucial point is that these are workers for whom the 'standard' employment relationship does not exist and whose working lives are therefore largely unregulated. These workers constitute the end-point of the subcontracting chain. They are invisible in terms of labour law and the IFA does not claim to reach them. Their presence represents an existential threat to union organisation (Gallin, 2001). They are, at the same time, the workers who most need a trade union and also the biggest obstacle to organising the industry as a whole.

It is in this fourth tier that the bulk of construction activities have become concentrated, allowing major construction services providers to exploit key aspects 
of local labour control regimes (Castree et al, 2004) such as informal labour, migrant labour, labour intermediaries, restrictions on organising, as well as lacking enforcement of national (health and safety) legislation (Interview, ILO expert). Construction has become one activity amongst others in Hochtief's portfolio, while its global operations typically involve small numbers of skilled, directly employed, project management staff (for example, 40 non-union office staff in Ukraine). In Malaysia, by contrast, $74 \%$ of the construction workforce does not have formal contracts and the vast majority of these (80\%) are foreign migrant workers. Although there is no longer a legal barrier to organising these workers, some "indirect restriction" is imposed (BWI, n.d.b), that is to say that employer clauses in contracts may effectively prohibit membership (Piper, 2007). In Ukraine, an estimated 55\% of GDP is the result of undeclared work though this may be an underestimate (Williams, 2007). Undocumented labour in construction is particularly associated with the growing private sector. In Brazil, a significant part of the construction workforce is made up by internal migrants: an estimated $46 \%$ of construction workers were migrants in 1996 (ILO, 2001: 11), while the proportion of undocumented and self-employed workers increased from $56.7 \%$ to $74.6 \%$ between 1981 and 1999 (ILO, 2001: 18). Thus, whilst the IFA might apply to the core workforce (although see note on Leighton above), the other tiers, who might be expected to benefit most, are effectively excluded.

\section{Applying the global agreement locally}


Union approaches to the IFA have been moulded by existing membership profiles, by national industrial relations systems and by unions' own traditions.

Insert Table 2 about here.

In Brazil, the unit of organisation has been the city, rather than the workplace or national level, which puts real barriers in the way of a broad company-specific strategy. Neither the local nor the national level is well placed to provide bargaining support or leadership. While the national confederation is dependent on affiliates for information on Hochtief activities; local affiliates have to rely on company channels. In this context, dissemination of the IFA and coordination of activities are problematic although the IFA might have a role in establishing the conditions for wider union coordination: "If the [IFA] made it possible to organise at the workplace, then the company would have to open doors" (Interview, local union official). However, in the absence of any facility to meet at work, or any knowledge of the IFA, this remains a "chicken and egg" problem. Industrial relations in the direct workforce are "based on conflict" (Interview, local union official); the subcontracted and informal workforce is not represented.

Trade union structure in Malaysia is fragmented by industry, by occupation and by region. Faced with employer hostility and with extensive restrictions on membership and action, unions have focussed on the core 'organisable' workforce. The UECI stresses that progress on the IFA must be based on a good relationship with the employer. UECI's core membership base is technical and supervisory staff. For these 
employees, Leighton's anti-unionism goes hand-in-hand with relatively high pay. Some attempt has been made to extend this scope to site workers, and the IFA has been part of this. A recruitment campaign during 2007 focussed on workplace safety, using the IFA as a benchmark of the type of labour relations elsewhere in the company. The campaign specifically targeted migrant workers, although it is also true that the most vulnerable - the undocumented - remain a significant proportion of the construction workforce.

Particularly given its weaknesses in parts of the sector, the union certainly sees the IFA, and company-wide unionism more generally, as a benefit in organising and bargaining. As a set of concrete commitments, however, the agreement has been found wanting. The BWI organised a workshop on the implementation of the IFA in Kuala Lumpar in 2006, which included board level representation as well as Malaysian management, together with the UECI and other unions. Leighton's own senior management, however, was not present: "They could not get Leighton around the table" (Interview, BWI official; BWI 2006a).

In Ukraine, the prospects for outsourced workers are held back by the legacy of Soviet era unionism. The continuing role of unions as service providers for their core, state sector membership has largely marginalised attempts to organise outsourced workers (see Kubicek, 2004). But, as large, privatised, conglomerates are dismantled, union memberships have become fragmented and uneven. Unions have remained strongest in the large, ex-state sector employers in the sector. Ukrstalkonstruktsiya, formed in 1973, is the contractor responsible for manufacturing and assembling the steel structure for the Dnipro stadium project. 
Here, union density is high (reported as $98 \%$ in one of the company's plants.) A union organiser sums up employment relations: "This company is a very good employer. They look after their workers. People don't have any problems here". From this position of paternalism and relative security, the IFA seems irrelevant to the permanent workforce: "Why would the union have to do with [the CSR] policies of a German company?" (Interview). Meanwhile, Hochtief's direct workforce in Ukraine, including 40 German and Ukrainian office-based staff, is not unionised and attitudes here reflect the image of unions in the country: "You just pay union dues and get nothing" (Interview, Hochtief employee).

In other circumstances, it is clear that IFAs can at least serve as the catalyst for action. The Ukrainian construction workers' union, UCBMIW used the Lafarge IFA successfully as part of the 2004 dispute over safety and working conditions at a cement works. Admittedly, the settlement in this case also required the threat of strike action - it was not enough to quote the terms of the agreement. Also, in contrast to construction, the Lafarge workforce was directly employed and $90 \%$ unionised. However, the IFA did serve to mobilise members and to signal to the company that this was, potentially, a company-wide grievance.

This evidence might suggest that IFAs work best where they are needed least. While they can be a focal point for union action, it is only possible to utilise them where effective union organisation already exists. The right to organise is best achieved by organising. In principle, the existence of a global negotiated agreement on freedom of association provides some foundation for local initiatives. As has been seen, though, opportunities are limited, not only by the structure of outsourcing, but also 
by existing patterns of union organisation. This case, therefore, raises questions not only about international solidarity, but also about solidarity between workers within national construction sectors undergoing rapid change. The transnational 'horizontal' dimension of agreements has, understandably, attracted interest, but if this is to mean anything, unions also need to address the 'vertical' reach of IFA provisions.

\section{Conclusion}

On the basis of this account of how the Hochtief IFA is used by management and trade unions at different levels, a number of points can be made. First, even seven years after the conclusion of the agreement the basic conundrum remains: whether to see the IFA as the foundation for organising or, rather, to see workplace organisation as the precondition for implementation of the IFA. In all three cases highlighted here, unions are faced with serious issues regarding recognition and organising at the workplace.

Second, although access to, and dialogue with, Hochtief senior management seems to be good, the absence of a standing reference group to monitor and implement the IFA constitutes a serious disadvantage. Such a forum might be pivotal in establishing a continuous working programme, and a first step in treating the IFA as enforceable objectives, rather than as aspirations. Such an approach might offer a focus for the formation of regular trade union networks with the BWI's national and local Hochtief subsidiaries. Also, in the absence of statutory control, Hochtief's own OHS 
procedures for the monitoring and certification of suppliers could be a model (see James et al, 2007) to extend the application of ILO standards and the framework agreement to subcontractors.

Third, an important distinction can be made in trade union approaches to IFAs: whereas the Hochtief IFA seems to be acted on more on an ad-hoc basis, the IFAs with Dutch construction MNCs seem to be working on a more proactive level. At the moment, union access to, and a good working relationship with, senior Hochtief management is very centralised, essentially in three officials from the main union BWI, IG BAU, and Hochtief General Works Council. At the same time, the BWI relies on affiliates' reports of problems to activate any mechanism to resolve them. However, such an ad-hoc approach to resolve grievances only accentuates the conundrum referred to above, particularly in the context of the fragmented and informal character of the construction industry. The difference in trade union approaches might stem from a home-country effect, i.e. resulting from the particular management-labour relations in the Dutch construction sector and/or the approach of FNV Bouw. Equally, the existence of reference groups in the Dutch construction IFAs may facilitate a more systematic and continuous use of the agreement. This resonates very much with BWI efforts to back the signature of framework agreements with education and information activities

International solidarity, in and of itself, cannot be the 'solution' because the most intractable problems in the industry are not primarily ones of international inequality. IFAs can play a part in building 'vertical' as well as 'horizontal' solidarity: not a new concept, but one that requires a focus on complementary strategies. On the one hand, 
'mandatory' IFA provisions require contractual status. This has been seen as unattainable in the private sector, but BWI has made progress on labour standards in public contracts, working with the International Contractors Association and the International Finance Corporation (the World Bank's lending arm). On the other hand, given the fluid structure of contracting, organising the value chain can only really be possible on an industry-wide basis. The International Organisation of Employers (IOE), for example, suggests that this is a serious possibility. In warning affiliates that signing an IFA is "ultimately an industrial relations issue" (2007: 14), the IOE holds out the prospect of a more ambitious union agenda:

It is too early to say definitely what the final destination is in this process, but perhaps some of the future issues that may emerge relate to sectoral approaches, attempts to alter existing agreements or perhaps even widening them to include reference to wages and conditions of work. (IOE, 2008)

If the agenda seems ambitious, unions might take hope from the way this is viewed by the employers.

\section{References}

Bosch, G. and P. Philips (eds) (2003), Building chaos: an international comparison of deregulation in the construction industry (London: Routledge).

Burawoy, M. (1985), The politics of production: factory regimes under capitalism and socialism (London: Verso).

BWI (2008), BWI delegation visits 2010 construction sites in South Africa, http://www.bwint.org/default.asp?index $=1483 \&$ Language=EN [accessed 04/04/2008] 
BWI (2007a), Interbeton is improving in the Gulf region, http://www.bwint.org/default.asp?Index=1280\&Language=EN [accessed 04/04/2008]

BWI (2007b), The dual face of Lafarge Group in Korea. All that glitters is not gold, http://www.bwint.org/pdfs/Lafargecase.pdf [accessed 04/04/2008]

BWI (2007c), Productive dialogue in Tanzania - Veidekke and BWI review International Framework Agreement (IFA), $\underline{\text { http://www.bwint.org/default.asp?index }=1042 \& \text { Language }=E N}$ [accessed 04/04/2008]

BWI (2006a), BWI/Hochtief workshop in Kuala Lumpur - looking for social partnership, http://www.bwint.org/default.asp?index=285\&Language=EN [accessed 03/12/2007]

BWI (n.d.a), Working and living conditions in Dubai are disproportionate for BWI and FNV Bouw, http://www.bwint.org/default.asp?index=662\&Language=EN [accessed 04/04/2008]

BWI (n.d.b), "Migration in Malaysia with Bro. Santhanasamy, Executive Secretary, Union of Employees in Construction Industry (UECI), http://www.bwint.org/default.asp?index=287\&Language=EN [accessed 25/03/2008].

Castree N., N. Coe, K. Ward and M. Samers (2004), Spaces of work: global capitalism and the geographies of labour (London: Sage).

Cremers, J., J.E. Dølvik and G. Bosch (2007), 'Posting of workers in the single market: attempts to prevent social dumping and regime competition in the EU', Industrial Relations Journal, 38, 6, 524-541.

Davies, S. (2008), Apprenticeships: a firm foundation. A report for UCATT (London: UCATT).

EMCC (2005), Trends and drivers of change in the European construction sector: mapping report, http://www.eurofound.europa.eu/emcc/publications/2005/ef04149en.pdf [accessed 02/12/2007]

Gallin, D. (2001) 'Propositions on trade unions and informal employment in times of globalisation,' Antipode, Vol. 33, No. 3, pp. 531-549

Hammer, N. (2008), 'International Framework Agreements in the Context of Global Production', 89-111, in K. Papadakis (ed), Cross-border social dialogue and 
agreements: an emerging global industrial relations framework? (Geneva: IILS/ILO).

Hammer, N. (2005), 'International Framework Agreements: global industrial relations between rights and bargaining', Transfer, 11, 4, 511-530.

Hale, A. and J. Wills (eds) (2005), Threads of labour: garment industry supply chains from the workers' perspective (Oxford: Blackwell).

Harvey, M. and F. Behling (2008), The evasion economy: false self-employment in the UK construction industry. A UCATT report (London: UCATT).

Hellmann, M. F. (2006), Contribution to IILS Workshop on 'Cross-border social dialogue and agreements: an emerging global industrial relations framework?, Panel 2: Implementation and monitoring of cross-border agreements', 15-16 December 2006, IILS/ILO (Geneva).

Hochtief (2007a), Annual Report 2006 (Essen: Hochtief)

Hochtief (2007b), Sustainability Report 2007 (Essen: Hochtief)

Hochtief, IG BAU and BWI (2000), Hochtief Code of Conduct in respect of the rights of its own employees and the employees of contractual partners, 15 March 2000, Berlin, http://www.bwint.org/default.asp?Index=44\&Language=EN [accessed 04/04/08]

Hyman, R. (2001), 'Trade union research and cross-national comparison', European Journal of Industrial Relations, 7, 2, 203-232.

IFBWW (2004), IFBWW experiences with Global Company Agreements, http://www.ifbww.org/files/global-agreements.pdf [accessed 04/04/08]

IFBWW (2003), IFBWW 'toolbox' on social dialogue and multinational companies, http://www.ifbww.org/files/startegy-mnc-en.pdf [accessed 04/04/2008]

ILO (2002) Women and Men in the Informal Economy: A Statistical Picture (Geneva: ILO)

ILO (2001), The construction industry in the twenty-first century: its image, employment prospects and skill requirements. Tripartite meeting on the construction industry (Geneva: ILO), http://www.ilo.ch/public/english/dialogue/sector/techmeet/tmcit01/tmcitr.pdf [accessed 03/12/2007]

IOE (2007) International framework agreements: an employer's guide, Geneva: International Organisation of Employers). 
IOE (2008), “International industrial relations”, http://www.ioe-emp.org/en/policyareas/international-industrial-relations/index.html [accessed 11/08/2008]

James, J., Johnstone, R., Quinlan, M. and Walters, D. (2007), “Regulating supply chains to improve health and safety", Industrial Law Journal, 36, 2, 163-187.

Kubicek, P.J. (2004), Organized labor in postcommunist states: from solidarity to infirmity (Pittsburg/PA: University of Pittsburgh Press).

Leighton (2007), Al Habtoor Leighton Group, http://www.leighton.com.au/verve/_resources/DS_Presentation_to_LHL_Investor _Group_Dec_07.pdf [accessed 04/04/2008]

Lillie, N. and I. Greer (2007), 'Industrial relations, migration, and neoliberal politics: the case of the European construction sector', Politics and Society, 35, 4, 551-581. Narayanan, Suresh and Lai Yew-Wah (2005) The Causes and Consequences of Immigrant Labour in the Construction Sector in Malaysia, International Migration 43 (5), 31-55

Piper, N. (2007) Enhancing the Migration Experience: Gendering Political Advocacy and Migrant Labour in Southeast and East Asia, IDRC Working Papers on Women's Rights and Citizenship, http://www.idrc.ca [accessed 26/03/2008]

Riisgaard, L. (2005), 'International framework agreements: a new model for securing workers rights?', Industrial Relations, 44, 4, 707-737.

Stansbury, N. (2005), "Exposing the foundations of corruption in construction", in Global Corruption Report 2005, Transparency International, pp36-50.

TUAC (2007), The OECD Guidelines for Multinational Enterprises. TUAC internal analysis of treatment of cases raised with National Contact Points February 2001December 2007, http://www.gurn.info/topic/oecdgdl/analys_ncp12_07.pdf [accessed 04/04/08]

UECI (2007), Brief report on organising Leighton Malaysia Sdn Bhd, 30 April 2007 (mimeo)

Villagarcia, S. and Cardoso, F. (1999) New supply chain network in Brazil's house construction industry, International Group for Lean Construction, http://www.ce.berkeley.edu/ tommelein/IGLC-7/ [accessed 03/04/2008]

Wells, J. (2007), 'Informality in the construction sector in developing countries', Construction Management and Economics, 25, 1, 87-93. 
Wills, J. (2002), 'Bargaining for the space to organise in the global economy: a review of the Accor-IUF trade union rights agreement.' Review of International Political Economy, 9, 4, 675-700.

Williams, C. (2007) Tackling Undeclared Work in Europe: Lessons from a Study of Ukraine, European Journal of Industrial Relations, 13: 219-236.

Williams, G. (2008), Managing by insecurity: work and managerial control under outsourcing, Competition and Change, 12, 3, 245-261. 
Table 1: BWI Framework Agreements in Construction

\begin{tabular}{|c|c|c|c|c|c|c|c|c|c|c|c|c|c|c|c|c|c|}
\hline & 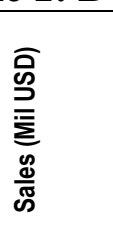 & 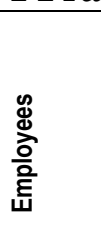 & Year & GUF & ILO Conventions & 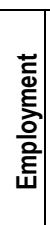 & $\begin{array}{c}\mathscr{d} \\
\stackrel{\varpi}{3} \\
3\end{array}$ & 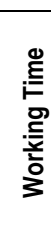 & 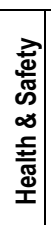 & 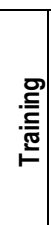 & 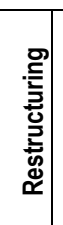 & 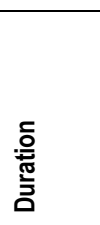 & $\begin{array}{l}\text { Supplier } \\
\text { relations }\end{array}$ & Implementation & 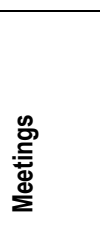 & $\begin{array}{l}\text { Trade union } \\
\text { involvment } \\
\text { (other than GUF) }\end{array}$ & $\begin{array}{l}\text { Mediation/ } \\
\text { arbitration }\end{array}$ \\
\hline Hochtief & $20,459.7$ & 46,847 & 2000 & BWI & ,the following agreements of the ILO' & $\mathrm{X}$ & $\mathbf{X}$ & $\mathbf{X}$ & $\mathrm{X}$ & & & Open & Mandatory & $\begin{array}{l}\text { Report to Executive } \\
\text { Board; officer } \\
\text { appointed for } \\
\text { application }\end{array}$ & & IG BAU & Joint (IFA) \\
\hline Skanska & $18,325.5$ & 56,000 & 2001 & BWI & $\begin{array}{l}29,87,98,100,105,111,135,138 \\
182 ; \operatorname{Rec} 143\end{array}$ & $\mathbf{X}$ & $\mathrm{X}$ & $\mathrm{X}$ & $\mathrm{X}$ & $\mathrm{X}$ & & 2 years & Mandatory & $\begin{array}{l}\text { Report to Executive } \\
\text { Board; officer } \\
\text { appointed for } \\
\text { application }\end{array}$ & Annual & FNV Bouw & Joint (IFA) \\
\hline $\begin{array}{l}\text { Ballast } \\
\text { Nedam }\end{array}$ & $1,728.3$ & 3,701 & 2002 & BWI & $\begin{array}{l}\text {,relevant conventions and } \\
\text { recommendations of the ILO' }\end{array}$ & $\mathbf{X}$ & $\mathbf{X}$ & $\mathrm{X}$ & $\mathbf{X}$ & & & Open & $\begin{array}{l}\text { Information/ } \\
\text { influence }\end{array}$ & $\begin{array}{l}\text { Joint application group } \\
\text { dealing with } \\
\text { compliance }\end{array}$ & & EWC & $\begin{array}{l}\text { Arbitration board } \\
\text { to be determined } \\
\text { jointly; decisions } \\
\text { are binding }\end{array}$ \\
\hline Impregilo & $4,100.3$ & 9,435 & 2004 & BWI & $\begin{array}{l}\text { 1, 29, 47, 87, 94, 95, 98, 100, 105, } \\
111,131,135,138,155,161,162 \\
\text { 167, 182; Rec116, Rec143 }\end{array}$ & $\mathrm{X}$ & $\mathrm{X}$ & $\mathrm{X}$ & $\mathrm{X}$ & $\mathrm{X}$ & & Open & Mandatory & Consulting group & Annual & National unions & Joint (IFA) \\
\hline Veidekke & $2,634.1$ & 6,351 & 2005 & BWI & $\begin{array}{l}29,87,98,100,105,111,135,138 \\
155,167,182 ; \operatorname{Rec} 143\end{array}$ & $\mathrm{X}$ & $\mathbf{X}$ & $\mathrm{X}$ & $\mathbf{X}$ & $\mathbf{X}$ & & 2 years & $\begin{array}{l}\text { Criterion/ } \\
\text { consequence }\end{array}$ & $\begin{array}{l}\text { Senior mgt responsible } \\
\text { for implementation; } \\
\text { local rep training for } \\
\text { monitoring }\end{array}$ & Annual & $\begin{array}{l}\text { Fellesforbundet, } \\
\text { Norsk } \\
\text { Arbeidsmandsfor } \\
\text { bundet, Chief } \\
\text { Shop Steward } \\
\end{array}$ & Joint (IFA) \\
\hline Lafarge & $22,324.9$ & 71,000 & 2005 & $\begin{array}{l}\text { BWI/ } \\
\text { ICEM }\end{array}$ & $\begin{array}{l}29,87,98,100,105,111,135,138, \\
155,182\end{array}$ & & $\mathrm{X}$ & $\mathrm{X}$ & $\mathrm{X}$ & $\mathrm{X}$ & & Open & $\begin{array}{c}\text { Criterion/ } \\
\text { consequence }\end{array}$ & $\begin{array}{l}\text { Reference group to } \\
\text { follow-up and monitor }\end{array}$ & Annual & & Joint (IFA) \\
\hline Royal BAM & $11,406.8$ & 30,338 & 2006 & BWI & $\begin{array}{l}29,87,98,100,105,111,135,138, \\
155,167,182 ; \operatorname{Rec} 143\end{array}$ & $\mathrm{X}$ & $\mathrm{X}$ & $\mathrm{X}$ & $\mathrm{X}$ & $\mathrm{X}$ & & Open & $\begin{array}{c}\text { Criterion/ } \\
\text { consequence }\end{array}$ & $\begin{array}{l}\text { Reference group to } \\
\text { follow-up and monitor }\end{array}$ & Annual & & Joint (IFA) \\
\hline $\begin{array}{l}\text { Volker } \\
\text { Wessels }\end{array}$ & $7,534.1$ & 17,000 & 2007 & BWI & $\begin{array}{l}1,29,47,87,94,95,98,100,105 \\
111,131,135,138,155,161,162 \\
167,182 ; \operatorname{Rec} 116, \operatorname{Rec} 143\end{array}$ & $\mathrm{X}$ & $\mathrm{X}$ & $\mathrm{X}$ & $\mathrm{X}$ & $\mathrm{X}$ & & Open & Mandatory & Monitoring group & Annual & & Joint (IFA) \\
\hline Italcementi & $8,616.7$ & 22,868 & 2008 & BWI & $\begin{array}{l}1,29,47,87,94,95,98,100,102 \\
105,111,116,131,135,138,155 \\
161,162,167,182 ; \operatorname{Rec} 143\end{array}$ & $\mathbf{X}$ & $\mathrm{X}$ & $\mathrm{X}$ & $\mathbf{X}$ & $\mathrm{X}$ & & Open & $\begin{array}{l}\text { Information/ } \\
\text { influence }\end{array}$ & Reference group & Annual & $\begin{array}{l}\text { BWl affiliated } \\
\text { home-country } \\
\text { unions, EWC }\end{array}$ & Joint (IFA) \\
\hline
\end{tabular}

Sources: Hoovers; MNC web sites and annual reports; GUF web sites; Sales and employee data from 2006 (Impregilo, VolkerWessels, Italcementi from 2007) 
Table 2: Using IFAs

\begin{tabular}{|c|c|c|c|c|c|c|c|}
\hline & Company/ownership & $\begin{array}{l}\text { National regulatory } \\
\text { (emp/TU) context }\end{array}$ & Migrant workers & Informal labour & $\begin{array}{l}\text { Trade union } \\
\text { structure }\end{array}$ & $\begin{array}{l}\text { Trade union } \\
\text { approach }\end{array}$ & Implications for IFA \\
\hline Brazil & $\begin{array}{l}\text { Subsidiary; extensive } \\
\text { subcontracting }\end{array}$ & $\begin{array}{l}\text { Collective labour law } \\
\text { proscribes city-based } \\
\text { unions }\end{array}$ & $\begin{array}{l}\text { Internal migration; } \\
\text { migrant workers } \\
\text { estimated at } 46 \% \text { of } \\
\text { construction } \\
\text { workforce }(1996)\end{array}$ & $\begin{array}{l}\text { Undocumented and } \\
\text { self-employed } \\
\text { workers estimated at } \\
74.6 \% \text { of construction } \\
\text { workforce (1999) }\end{array}$ & $\begin{array}{l}\text { City-based trade } \\
\text { unions; around } 500 \\
\text { construction unions }\end{array}$ & & $\begin{array}{l}\text { City focus at odds } \\
\text { with pursuit of } \\
\text { company-specific } \\
\text { strategy }\end{array}$ \\
\hline Malaysia & $\begin{array}{l}\text { Leighton; significant } \\
\text { subcontracting }\end{array}$ & $\begin{array}{l}\text { 'indirect restrictions' } \\
\text { on organising; UECI } \\
\text { has recognition } \\
\text { problems with } \\
\text { Leighton }\end{array}$ & $\begin{array}{l}\text { Indonesian migrants; } \\
80 \% \text { of informal } \\
\text { workers are migrants }\end{array}$ & $\begin{array}{l}74 \% \text { of workforce } \\
\text { informal }\end{array}$ & $\begin{array}{l}\text { Fragmented by } \\
\text { industry, occupation, } \\
\text { region }\end{array}$ & $\begin{array}{l}\text { Recognition problems } \\
\text { force UECI to } \\
\text { represent (and recruit) } \\
\text { on basis of individual } \\
\text { representation }\end{array}$ & $\begin{array}{l}\text { No union } \\
\text { representation of } \\
\text { subcontracted } \\
\text { workers; forced to } \\
\text { organise } \\
\text { subcontractors off-site }\end{array}$ \\
\hline Ukraine & $\begin{array}{l}\text { Own division; limited } \\
\text { subcontracting to } \\
\text { major/large? } \\
\text { Contractors }\end{array}$ & & & $\begin{array}{l}55 \% \text { of GDP is } \\
\text { estimated to result } \\
\text { from undeclared work }\end{array}$ & $\begin{array}{l}\text { Strong union } \\
\text { presence in ex-state } \\
\text { companies }\end{array}$ & & $\begin{array}{l}\text { IFA provisions not } \\
\text { included in contracts; } \\
\text { very limited } \\
\text { knowledge by } \\
\text { contractors }\end{array}$ \\
\hline
\end{tabular}

